\title{
NEURAL NETWORK APPLICATION FOR THE ANALYSIS OF THE NUTRITION AND ENVIRONMENT EFFECT TO MICROBIAL GROWTH RATE ON FERMENTED SOYBEAN PATTY (TEMPE) FERMENTATION
}

\author{
Nur Yanti $^{1 *}$, Fathur Zaini Rachman ${ }^{2}$ \\ 1,2 Jurusan Teknik Elektronika, Politeknik Negeri Balikpapan \\ *e-mail:nur.yanti@poltekba.ac.id
}

\begin{abstract}
The problems that still often faced by the industry in the processing of soybeans into tempe today is the lengthy process of fermentation is about 72 hours. The Long of fermentation will certainly slow down the productivity tempe. The long fermentation process is influenced by several factors such as the growth of microbial as microorganisms that do fermentation activity. The growth rate of microbes in the fermentation process is influenced by the content of the nutrient or nutrients that support the microbes can multiply rapidly perform cell division. In addition to nutrients, environmental factors such as acidity and temperature also affects to the growth rate of microbes. By applying Neural Network (Artificial Neural Networks), can produce a proper analysis to take into account the adequacy of nutrients, temperature stability and $\mathrm{pH}$ which accelerates the growth of tempe mold, so the fermentation process will go faster and the quality of tempe like the flavor and the aroma produced is better. The method that used is the combination method of qualitative and quantitative. The results of this study are the output data analysis results using a neural network to identify the composition of the nutrient content, temperature and $\mathrm{pH}$ is good and right for the fermentation process. The learning process of the neural network generates output data with high accuracy, namely with 2-4-1 architecture, learning rate 0:02, MSE 0.000999 <target error at epoch 3150001 for nutrient content analysis. As for the temperature and $\mathrm{pH}$ stability analysis, learning outcomes network architecture yields 2-3-1, with learning rate 0:02, MSE 0.000986 <target error at epoch 295. 0001 performance results for the performance of the neural network is better than other architectures.
\end{abstract}

Keywords: Tempe (Fermented Soybean Patty) Fermentation, Environment, Nutrients, Neural Network

\section{Introduction}

The material processing that is soybeans into tempe includes the process of soaking, boiling and fermentation. The quality and speed in the production process tempe affected by environmental conditions such as $\mathrm{pH}$ (degree of acidity) and temperature. In the fermentation conditions are optimal, tempeh mold growth will be increased so that the process will go faster and the quality of tempe like flavor and aroma produced is better. Fermentation of foods are as a result of activities of some types of microorganisms like bacteria, yeasts and molds. Microorganisms that ferment foodstuffs can produce favorable changes (the desired fermentation product) and an adverse change (destruction of foodstuffs). Therefore we need a proper analysis related to environmental influences on microbial growth rate in the fermentation process to produce tempe which has good quality. Aside from being influenced by the environment, the process of fermentation is also influenced by nutrients needed for the growth of microbial cells. The better nutrients in the substrates resulting in faster cell growth and the increase of the cell size. The higher the rate of cell growth so the faster microbes cause fermentation in tempe.

Neural Network or artificial neural network is a network that has the ability to map the input pattern through learning model of supervision (supervised learning) and unsupervised learning. The resulting mapping will show the relation between the input patterns in a more compact representation of the original data and accurately maintain relation with its topology. 


\section{Research Methods}

In this research, neural network learning process consisting of training and testing to analyze the composition of the nutrient content, temperature stability and $\mathrm{pH}$ for microbial growth pace in the process of fermentation. The research method is a combination of qualitative and quantitative research. The type of combination research is a of Exploratory Sequential Design, which is in the begining of the research using qualitative methods and the next phase using quantitative methods.

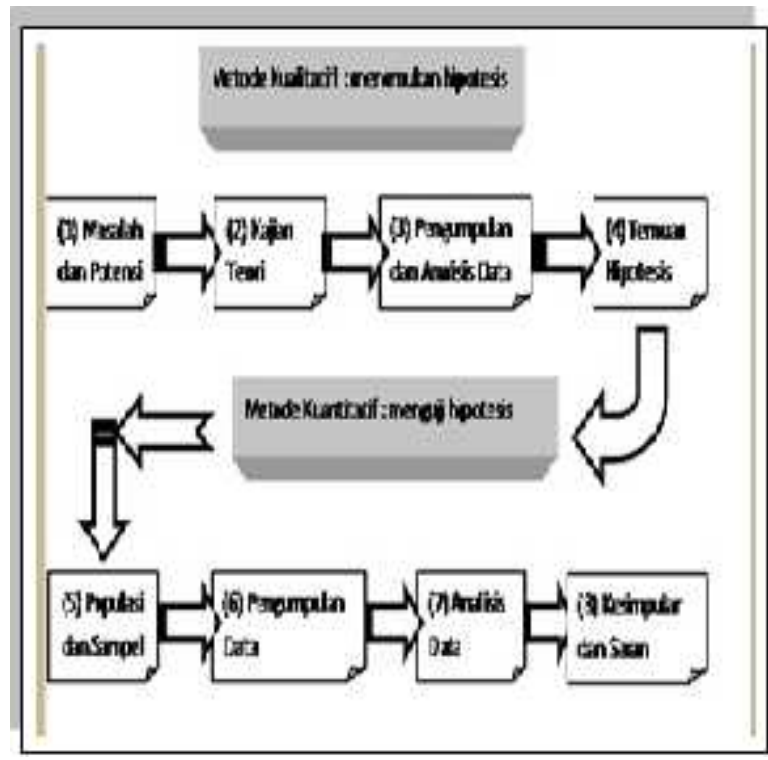

Picture.1 Flowchart The Research Methodology

\section{Result of The Research}

In this research, the analysis of nutrients and environmental influences on the rate of microbial growth in fermentation. Nutrients are required as a component element of the formation of microbial cells, among others, carbon, nitrogen, protein, hydrogen, lipids, and nucleic acids. While the environment that affect microbial growth is the degree of acidity $(\mathrm{pH})$ and temperature.

\subsection{The Neural Network Analysis Methods}

The analysis Steps using a neural network as follows:

1. Data training distribution, $(70 \%$ or 4 data) as training data, $30 \%$, or 2 data for testing.

2. Data is transformed by the function activation and encoding scheme used.

3. Back propagation algorithm (backpropagation).

4. The Steps of back propagation algorithm:

a. Initialization The initial weight

b. Feedforward input patterns until the response reaches the output layer.

c. The response generated in the output layer is compared with the target value, and calculated the MSE. If it has been fulfilled in accordance with fault tolerant of 0001, then the counting process is stopped. But on the contrary if the stopping criterion has not been met then proceed to step 4.

d. Moving backward from the output layer back to the input layer and adjust the weights and repeat the process.

e. Calculate the value of Mean Square Error (MSE) of the results of training the neural network algorithm (backpropogation) for evaluation in accordance with the target.

The results of the observations and literature on the tempe fermentation process in the data elements get the nutritional components to the average composition of microbial cells (on \% dried weight). as follows: 
Table 1 The average composition of microbial cells data Elements

\begin{tabular}{|l|c|c|c|}
\hline \multirow{2}{*}{$\begin{array}{c}\text { Nutrition } \\
\text { Element }\end{array}$} & \multicolumn{2}{|c|}{$\begin{array}{c}\text { Microbe } \\
\text { (\% dried weight) }\end{array}$} & \multirow{2}{*}{$\begin{array}{c}\text { Target } \\
\text { (Hours) }\end{array}$} \\
\cline { 2 - 3 } & Bakterium & $\begin{array}{c}\text { Kapang/ } \\
\text { fungus }\end{array}$ & \\
\hline Carbon & 48 & 48 & 24 \\
\hline Nitrogen & 12 & 56 & 24 \\
\hline Protein & 55 & 32 & 40 \\
\hline Hydrogen & 9 & 49 & 24 \\
\hline Lipids & 7 & 8 & 40 \\
\hline Nucleic & 23 & 5 & 72 \\
acids & & & \\
\hline
\end{tabular}

\subsection{Transformation Data}

Data is transformed into the interval $[0,1]$. But it would be better if it is transformed into smaller intervals, for example on the interval $[0.1,0.9]$. Linear transformation is used to transform data into interval $[0.1,0.9]$ are:

$$
=\frac{0.8(-)}{-}+0.1
$$

If $\mathrm{a}$ is the minimum data and $\mathrm{b}$ is the maximum data, and $\mathrm{x}$ is the actual value.

\section{Data transformation result}

Table 2. The average Elements data composition of microbial cells

\begin{tabular}{|l|c|c|c|}
\hline $\begin{array}{c}\text { Nutrition } \\
\text { Element }\end{array}$ & \multicolumn{2}{|c|}{ Microbe (\% dried weight) } & $\begin{array}{c}\text { Target } \\
\text { (Hours) }\end{array}$ \\
\hline Carbon & 0.8 & 0.9 & 0.1 \\
\hline Nitrogen & 0.2 & 0.9 & 0.1 \\
\hline Protein & 0.9 & 0.5 & 0.4 \\
\hline Hydrogen & 0.1 & 0.8 & 0.1 \\
\hline Lipids & 0.1 & 0.1 & 0.4 \\
\hline $\begin{array}{l}\text { Nucleic } \\
\text { acids }\end{array}$ & 0.4 & 0.1 & 0.9 \\
\hline
\end{tabular}

Here is presented a model of neural network in one iteration (one epoch): At initialization set:

The data used in the training process is $1 \mathrm{st}$ data to the 4th data.

The number of neurons in the input layer $=2$

The number of neurons in the hidden layer $=4$

The number of neurons in the output layer $=1$

Learning rate $(\alpha)=0.02$

Maximum epoch $=1000$

Target error $\quad=0.001$
The first weight as follows:

\section{Proses Training}

- The first weight input to the hidden layer (v) :

$$
\begin{aligned}
& \text { bobotawa1_input }= \\
& \begin{array}{rr}
-0.2461 & 13.9913 \\
5.0167 & 9.7637 \\
-4.3031 & 11.0424 \\
-3.1423 & 12.5101
\end{array}
\end{aligned}
$$

- The first bias weight to the hidden layer (vo) :

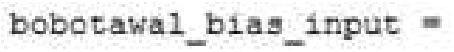

$$
\begin{array}{r}
-6.8709 \\
-10.2763 \\
-6.5115 \\
-9.9859
\end{array}
$$

- The first weight of hidden layer to output

$$
\begin{aligned}
& \text { gobJzand_Lapisan = } \\
& -0.9236 \quad 0.6983 \quad 0.8600 \quad 0.3578
\end{aligned}
$$

- The first bias weight to the output (wo) :

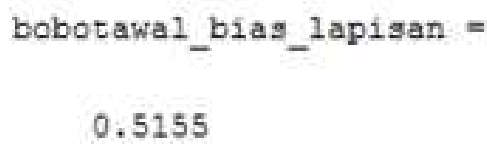

Epoch-1 (Data-1)

The operations of hidden layer :

$$
\begin{aligned}
\mathbf{z}_{-} \mathbf{i n}_{\mathbf{j}}= & +\sum=\dot{ }= \\
\mathrm{z}_{-} \mathbf{i n}_{1}= & (-6.8709)+(-0.2461) \cdot(0.8)+ \\
& (13.9913) .(0.8) \\
= & 4.12526
\end{aligned}
$$

With the same way for $z_{-} i n_{2}, z_{-} i n_{3}$ dan $z_{-} i n_{4}$

\section{Activation :}

$$
\begin{aligned}
& \mathbf{Z}_{\mathbf{j}}=\mathbf{f}\left(\mathbf{z}_{-} \mathbf{i n}_{\mathbf{j}}\right) \\
& \mathrm{Z}_{1}=\frac{1}{1+}=\frac{1}{4.12526}=0.98
\end{aligned}
$$

With the same way for $\mathrm{z}_{2}, \mathrm{z}_{3}$ dan $\mathrm{z}_{4}$ 


\section{The operation for output layer:}

$$
\begin{aligned}
\mathbf{y}_{\_} \mathbf{i n}_{\mathbf{k}}= & +\sum=\ldots \\
y_{-} \text {in }= & (0.5155)+(-0.9286) .(0.98)+ \\
& (0.6983) .(0.82)+(0.8680) .(0.25)+ \\
& (0.3575) .(0.076) \\
= & 0.42
\end{aligned}
$$

\section{Activation :}

$$
\begin{aligned}
\mathbf{y}_{\mathbf{k}} & =\mathbf{f}^{\prime}\left(\mathbf{y}_{-} \mathbf{i n}_{\mathbf{k}}\right) \\
\mathbf{y} & =\frac{1}{1+-\overline{(0.42)}} \\
& =0.606
\end{aligned}
$$

Error $=$ Target Error - Output

$$
\begin{aligned}
& =(0.1)-(0.606) \\
& =(-0.506)
\end{aligned}
$$

Sum of squares error $=(-0.506)^{2}=0.2560$

$$
\begin{aligned}
\boldsymbol{\delta}_{\mathbf{k}} & =\left(\mathbf{t}_{\mathbf{k}}-\mathbf{y}_{\mathbf{k}}\right) \cdot \mathbf{f}^{\prime}\left(\mathbf{y}_{-} \mathbf{i n}_{\mathbf{k}}\right) \\
\delta & =\left(\mathrm{t}_{\mathrm{k}}-\mathrm{y}_{\mathrm{k}}\right) \cdot \frac{1}{1+}=-1-\left(\frac{1}{-}-1-\frac{1}{-}\right) \\
& =(0.1-0.606) \cdot(0,606) \cdot(1-0.606) \\
& =-0.12
\end{aligned}
$$

Correction weights (repair value $\mathrm{w}_{\mathrm{jk}}$ ) :

$$
\begin{aligned}
\mathbf{w}_{\mathbf{j k}} & =\boldsymbol{\alpha} \cdot \boldsymbol{\delta}_{\mathbf{k}} \cdot \mathbf{z}_{\mathbf{j}} \\
\mathrm{w}_{1} & =\alpha \cdot \delta \cdot \mathbf{z}_{1} \\
& =(0.02) \cdot(-0.12) .(0.98) \\
& =-0.0023
\end{aligned}
$$

With the same way for $\mathrm{w}_{2}, \quad \mathrm{w}_{3}$ dan $\mathrm{w}_{4}$

Bias Correction (repair value $\mathrm{w}_{\mathrm{ok}}$ ) :

$$
\begin{aligned}
\mathbf{w}_{\mathbf{o k}} & =\boldsymbol{\alpha} \cdot \boldsymbol{\delta}_{\mathbf{k}} \\
\mathrm{w}_{\mathrm{o}} & =\alpha \cdot \delta \\
& =(0.02) \cdot(-0.12) \\
& =-0.0024 \\
\boldsymbol{\delta}_{\mathbf{i n}} \mathbf{n}_{\mathbf{j}} & =\sum= \\
\delta \_\mathrm{in}_{1} & =\delta . \mathrm{w}_{1} \\
& =(-0.12) .(-0.9286) \\
& =0.11
\end{aligned}
$$

Error Information:

$$
\begin{aligned}
\boldsymbol{\delta}_{\mathbf{j}} & =\boldsymbol{\delta}_{-} \mathbf{i n}_{\mathbf{j}} \cdot \mathbf{f}^{\prime}\left(\mathbf{z}_{-} \mathbf{i n}_{\mathbf{j}}\right) \\
\delta_{1} & =\delta_{-} \mathbf{i n}_{1} \cdot \frac{1}{1+}=\frac{1}{-1} \cdot 1-\left(\frac{1}{1+}=\frac{1}{-1}\right) \\
& =(0.11) .(0.73) .(1-0.73) \\
& =0.021
\end{aligned}
$$

The changes the input to hidden layer weights. Weight Correction (repair value $\mathrm{v}_{\mathrm{ij}}$ ):

$$
\begin{aligned}
\mathbf{v}_{\mathbf{i j}} & =\boldsymbol{\alpha} \cdot \boldsymbol{\delta}_{\mathbf{j}} \cdot \mathbf{x}_{\mathbf{i}} \\
\mathrm{v}_{11} & =\alpha \cdot \delta_{1} \cdot \mathbf{x}_{11} \\
& =(0.02) .(0.021) .(0.8) \\
& =0.00033
\end{aligned}
$$

The changes of biar weight hidden layer.

Bias correction (repair value $\mathrm{v}_{\mathrm{oj}}$ ) :

$$
\begin{aligned}
\mathbf{v}_{\mathbf{o j}} & =\boldsymbol{\alpha} \cdot \boldsymbol{\delta}_{\mathbf{j}} \\
\mathrm{v}_{\mathbf{0} 1} & =\alpha \cdot \delta_{1} \\
& =(0.02) \cdot(0.021) \\
& =0.00042 \\
\mathrm{v}_{02} & =\alpha \cdot \delta_{2} \\
& =(0.02) \cdot(-0.017) \\
& =-0.00034
\end{aligned}
$$

Repair bias and weights.

New weight input to the hidden layer:

$$
\begin{aligned}
\mathbf{v}_{\mathbf{i j}}(\text { new }) & =\mathbf{v}_{\mathbf{i j}}(\text { old })+\mathbf{v}_{\mathbf{i j}} \\
\mathbf{v}_{11}(\text { new }) & =\mathbf{v}_{11}(\text { old })+\mathbf{v}_{11} \\
& =(-0.2461)+(0.00033) \\
& =-0.245
\end{aligned}
$$

Bobot baru bias ke hidden layer :

$$
\begin{aligned}
\mathbf{v}_{\mathbf{o j}}(\text { new }) & =\mathbf{v}_{\mathbf{o j}}(\text { old })+\mathbf{v}_{\mathbf{o j}} \\
\mathrm{v}_{\mathrm{ol}}(\text { new }) & =\mathbf{v}_{\mathrm{ol}}(\text { old })+\mathbf{v}_{\mathbf{o} 1} \\
& =(-6.8709)+(0.00042) \\
& =-6.8704
\end{aligned}
$$

The new weights hidden to output layer.

$$
\begin{aligned}
\mathbf{w}_{\mathbf{j k}}(\text { new }) & =\mathbf{w}_{\mathbf{j k}}(\mathbf{o l d})+\mathbf{w}_{\mathbf{j k}} \\
\mathrm{w}_{1}(\text { new }) & =\mathbf{w}_{1}(\text { old })+\mathrm{w}_{1} \\
& =(-0.9286)+(-0.0023) \\
& =-0.9309
\end{aligned}
$$

In the second data, performed operations using the final processing results weights first data as the first weights. This process is repeated until theMaximum epoch (1000) or MSE < target error (0001).

Here is the final weight after the epoch to 315:

- The last input weight to the hidden layer :

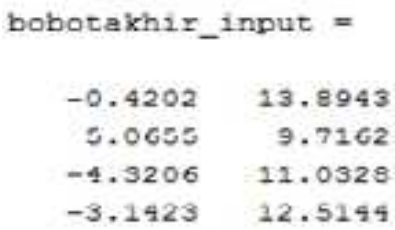

- The last bias weight to the hidden layer : 
bobotakh1I_bias_input =

$-7.0647$

$-10.2938$

$-6.5201$

$-9.9801$

- Te last weight to the output :

bobotakhir_lapisan =

$$
\begin{array}{lllll}
-1.0076 & 0.3273 & 0.6531 & -0.1046
\end{array}
$$

- The last bias weight to the output :

bobotakinir_bias_lapisan =

\subsection{8}

MATLAB simulation results for the target as following:

$\mathrm{y}=$

$$
\begin{array}{llll}
0.1006 & 0.1448 & 0.4108 & 0.0568
\end{array}
$$

The results of neural network performance resulting from the process of training as follows:

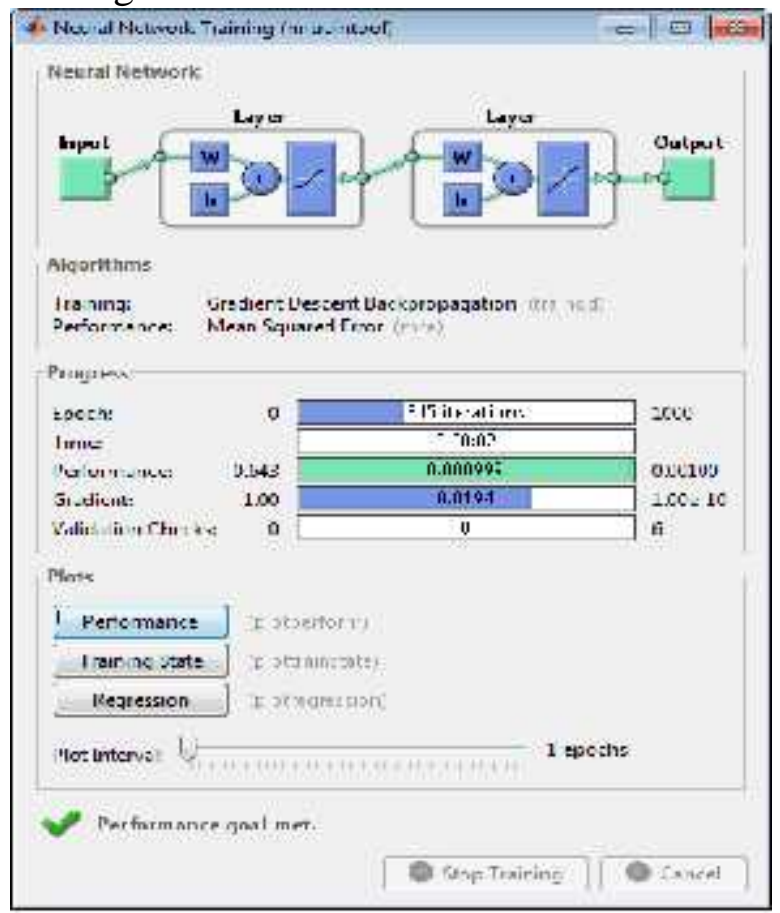

Picture 2. The training proses of neural network

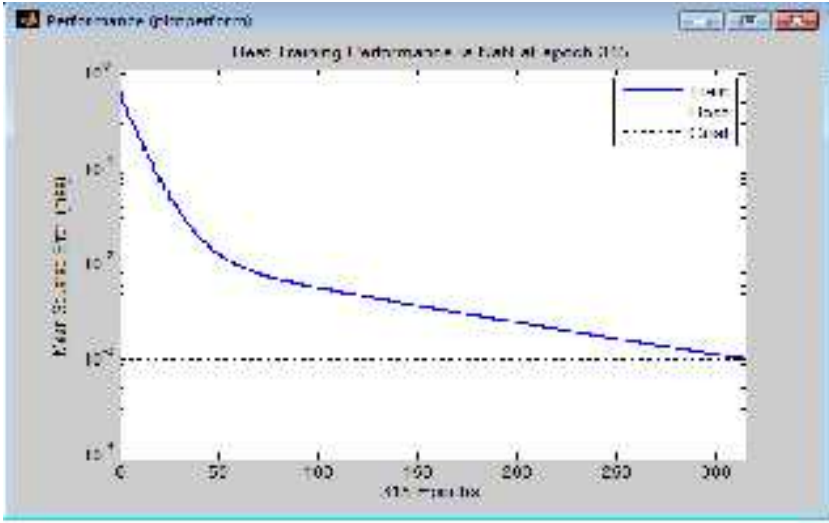

Picture 3. The training performance of neural network on epoh to-315

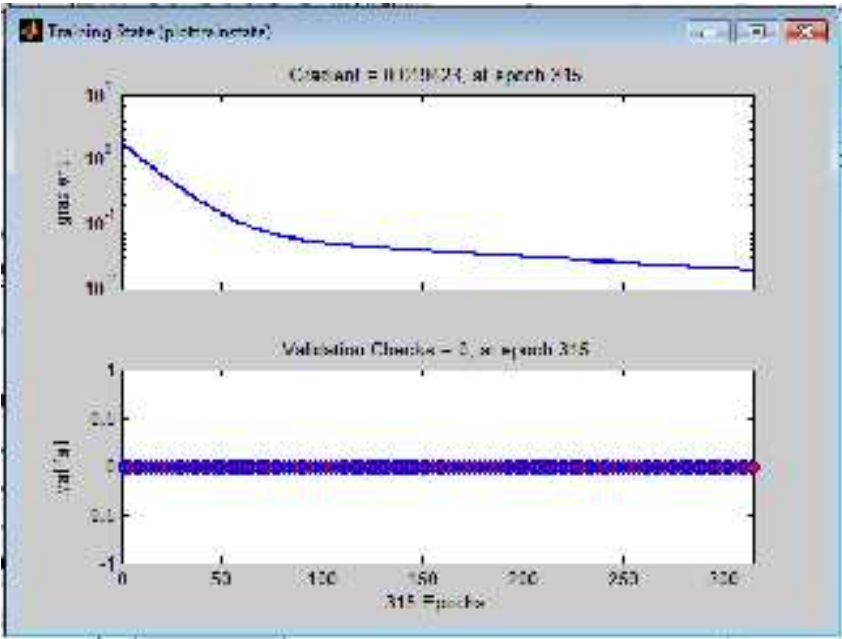

Picture 4. Gradient and validation of neural network training

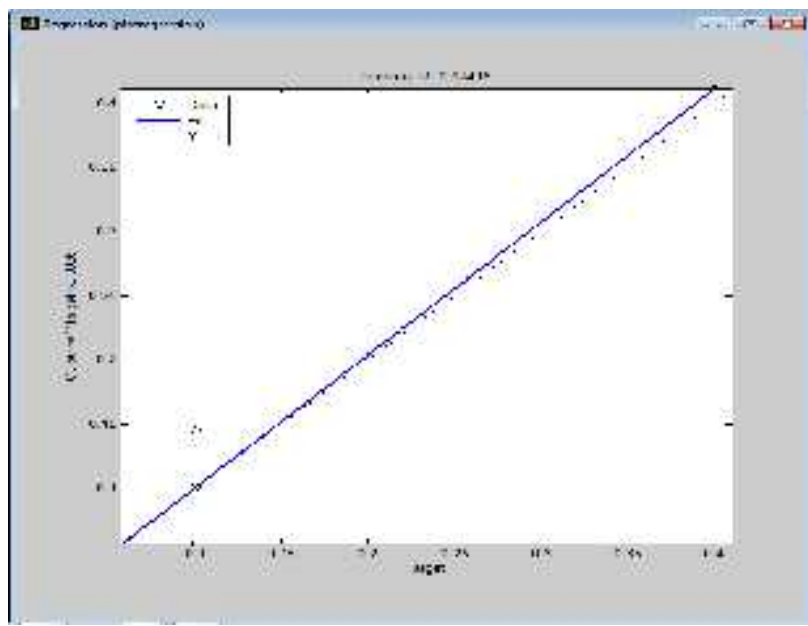

Picture 5. Regresi training proces of neural network 


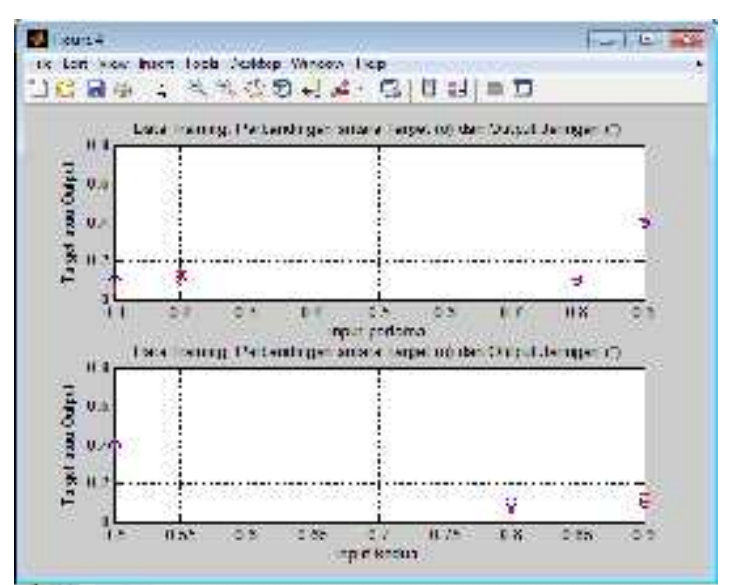

Picture 6. The differences of target and both output input data

Do the same thing on the data number 2 and analysis of temperature and PH stability. The results of the learning neural network which includes training and testing process using backpropagation algorithm to analyze the effect of nutrients on the rate of growth of microbes on fermentation resulted in identification of nutrient composition in the process of fermentation to produce tempe with good quality and fermentation duration is not too long.

Table 3. Elements average data of the cells microbial composition NN results

\begin{tabular}{|l|c|c|c|c|}
\hline \multirow{2}{*}{ Nutrition } & $\begin{array}{c}\text { Microbe } \\
(\%) \text { dried } \\
\text { weight }\end{array}$ & $\begin{array}{c}\text { Target } \\
\text { (Hours) }\end{array}$ & $\begin{array}{c}\text { Target } \\
\text { Transfor } \\
\text { mation) }\end{array}$ & $\begin{array}{c}\text { Target } \\
\text { NN } \\
\text { resul }\end{array}$ \\
\hline Carbon & 48 & 24 & 0.1 & 0.1 \\
\hline Nitrogen & 56 & 24 & 0.1 & 0.1 \\
\hline Lipids & 32 & 40 & 0.4 & 0.3 \\
\hline Protein & 49 & 24 & 0.1 & 0.4 \\
\hline $\begin{array}{l}\text { Nucleic } \\
\text { acids }\end{array}$ & 8 & 40 & 0.4 & 0.9 \\
\hline Hydrogen & 5 & 72 & 0.9 & 0.0556 \\
\hline
\end{tabular}

Table 4. Temperature, $\mathrm{PH}$ and fermentation time $\mathrm{NN}$ results

\begin{tabular}{|l|c|c|c|c|c|}
\hline $\begin{array}{l}\text { Microbe } \\
\text { Types }\end{array}$ & $\begin{array}{c}\text { Te } \\
\mathrm{mp} \\
\left({ }^{\circ} \mathrm{C}\right)\end{array}$ & PH & $\begin{array}{c}\text { Targ } \\
\text { et } \\
\text { (Ho } \\
\text { urs) }\end{array}$ & $\begin{array}{c}\text { Target } \\
\text { (Transfo } \\
\text { rmation) }\end{array}$ & $\begin{array}{c}\text { Target } \\
\text { NN } \\
\text { result }\end{array}$ \\
\hline $\begin{array}{l}\text { Psikrofi } \\
\text { lik }\end{array}$ & 15 & 3 & 40 & 0.4 & 0.3 \\
\hline $\begin{array}{l}\text { Mesop } \\
\text { hilic }\end{array}$ & 25 & 6 & 24 & 0.1 & 0.1 \\
\hline $\begin{array}{l}\text { Thermo } \\
\text { philic }\end{array}$ & 60 & 9 & 72 & 0.9 & 0.9 \\
\hline
\end{tabular}

Kapang/fungus on a fermentation process based on the temperature and $\mathrm{pH}$ of the proper order to accelerate the growth of microbes at a temperature of 25 ${ }^{\circ} \mathrm{C}$ with 6 degrees of acidity.

\section{Conclusion}

The results showed the influence of nutrients and environmental analysis in accelerating the growth of microbes in the fermentation process, using artificial neural network with backpropagation algorithm to produce architecture that forms 2-4-1, with 00:02 learning rate, maximum error epoch of 1000 and 0001 targets, generating (MSE ) amounted to 0.000999 <target error at epoch 3150001 $<$ maximum epoch 1000. Results showed learning neural network between the output and the target does not have a significant difference in this case can be seen from Figure 5 regression training process. So that the component elements of molds cells as microbes play an important role in the fermentation process that requires nutrients include carbon, nitrogen, lipids, proteins, nucleic acids have been fulfilled for the acceleration of the growth of microbes in the fermentation process while the hydrogen content is not adequate. From the analysis of temperature and $\mathrm{PH}$, molds can grow well at a stable temperature at $25^{\circ} \mathrm{C}$ with 6 degrees of acidity. 


\section{Suggestion}

In order to obtain optimal learning algorithm results, preferably constructed network topology with the right architecture, taking into account the data pattern. Can using neural networks with other algorithms or hybrid algorithm to optimize network performance. Determination of the first weight during the training data process, as well as the targets specified error affects the speed of improvement of the weights, so it needs to set the first weight that ideal for the network to the end of the weights as well as the achievement of error can be achieved with a relatively short iterative process.

\section{References}

[1] Drs. Siang Jek Jong, M.Sc. 2009. Jaringan Syaraf Tiruan \& Pemrogramannya Menggunakan Matlab. Andi Yogyakarta.

[2] Fausett, L. 1994. Fundamentals of Neurals Network, Architecture, Algorithms, and Applications, Prentice Hall.

[3] Haykin, S. 1994. Neural Networks, a Comprehensive Foundation, Prentice Hall.

[4] Kosko, B. 1992. Neural Networks and Fuzzy Systems : A Dynamic Systems Approach to Machine Intelligence, Prentice Hall.

[5] LiMin Fu. 1994. Neural Networks in Computer Intelligence. McGraw-Hill, Inc.

[6] Kusumadewi, D. 2003. Artificial Intelligence, Teknik dan Aplikasi. Graha Ilmu. Yogyakarta.

[7] Kusumadewi, D. 2004. Membangun Jaringan Syaraf Tiruan. Graha Ilmu. Yogyakarta

[8] Nur Yanti, Maria Ulfa. 2015. Aplikasi Jaringan Syaraf Tiruan Untuk Clustering Polutan Kimia Penyebab Pencemaran Udara. Jurnal Teknologi Terpadu Politeknik Negeri Balikpapan ISSN 23386649. 